\title{
Hvad er DOI og hvorfor skal vi bruge det?
}

Af Niels Erik Frederiksen

\section{Hvad er en DOI?}

Digital Object Identifier (DOI) er et unikt og permanent digitalt datanavn på et objekt. Her skal man lægge mærke til ordenes rækkefølge, der er nemlig ikke tale om et datanavn på et digitalt objekt. Objektet kan være såvel en fysisk som digital ting, et maleri, en gammel DVD eller et manuskript. I de fleste tilfælde er der dog tale om online elementer, som f.eks. tidsskriftsartikler eller e-bøger. Til enhver DOI er der knyttet metadata og drejer det sig om en digital ressource, vil metadata indeholde ressourcens aktuelle URL.

Mens en URL genereres ud fra det sted den pågældende ressource er placeret, er DOI-systemet bygget op omkring et centralt register. Når en bruger klikker på en DOI, sendes der en besked til det centrale register, og drejer det sig om en digital ressource sendes den tilknyttede URL tilbage til brugerens browser. Det hele sker på et splitsekund. Afhængigt af udbyderens valg vil brugeren herefter enten have direkte adgang til ressourcen eller få yderligere oplysninger om, hvordan der kan opnås adgang.

ÆEndres ejerskabet og/eller flyttes ressourcen til en anden URL, skal dette blot registreres centralt i DOIregisteret, herefter vil alle tilknyttede DOI'er pege på de nye URL-adresser ${ }^{1}$. Linket er således stabilt og permanent i modsætning til gamle URL'er. En DOI peger nemlig på objektet, ikke på placeringen.

Det var netop problemet med ustabile URL'er, der i 1990'erne fik dele af forlagsverdenen til at efterspørge et alternativ til URL-henvisningerne. ${ }^{2}$ I 1997 etableredes The International DOI Foundation, hvis opgave det blev at udvikle det nu veletablerede DOI-system. ${ }^{3}$ I 2000 så det første DOI-leverandører dagens lys og de første elektroniske artikler fik tildelt DOI ${ }^{4}$. Endeligt blev DOI-systemet i 2010 anerkendt som en ISO standard. ${ }^{5}$

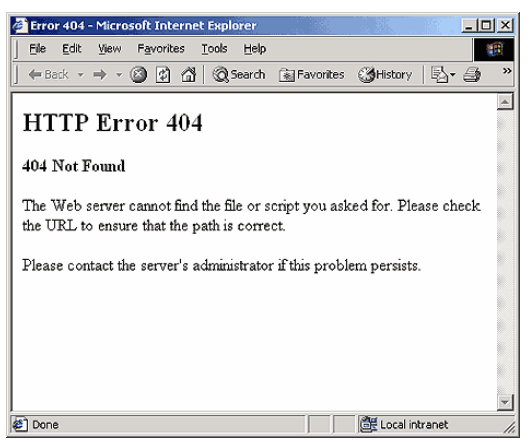

\footnotetext{
${ }^{1}$ Ænndringer sker typisk via DOI-leverandøen f.eks. CrossRef

${ }^{2}$ Følgende foreninger tog de indlednede initiativer: International Publishers Association; International Association of Scientific, Technical and Medical Publishers; Association of American Publishers. Problemet var: "Over time, fewer and fewer links in references work: studies have found that in some cases within four years half of the links in an article are broken without the use of persistent identifiers" http://www.doi.org/driven by doi/DOI Marketing Brochure.pdf ${ }^{3}$ http://www.doi.org/index.html

${ }^{4}$ Første DOI-leverandør var CrossRef: http://www.crossref.org/

${ }^{5}$ http://www.iso.org/iso/news.htm?refid=Ref1561 og http://www.doi.org/doi handbook/1 Introduction.html http://doi.org/10.1000/182
} 


\section{Og hvorfor anbefaler vi så brugen af DOI?}

Den nok mest åbenlyse fordel skulle gerne fremgå af ovenstående gennemgang, nemlig den stabile linkning. Dette har nu afstedkommet, at alle de mest udbredte citationsstandarder (APA, Chicago, Harvard osv) anbefaler brugen af $\mathrm{DOI}^{6}$. Alene i kraft af disse anbefalinger bør ethvert seriøst tidsskrift give adgang til denne service. Når det først er blevet en del af en gængs standard, vil manglen på en sådan ofte blive tolket som en kvalitetsmangel.

På Statsbiblioteket og AU Library har vi valgt CrossRef som vores DOI-leverand $\varnothing$ r. Dette giver flere fordele, en af dem er, at alle vores DOI-registrerede ressourcer indekseres $i$ the CrossRef metadata database ${ }^{7}$, som anvendes af mange organisationer og biblioteker - blandt andre WorldCat. ${ }^{8}$ Dette $\varnothing$ ger selvsagt synligheden.

En anden fordel ved CrossRef er, at de anvender DOI'en til at indsamle citationer. Det samme gælder Altmetrics. ${ }^{9}$ Altmetrics er en relativ ny nettjeneste, der tager kampen op med flere af de gængse citationsindeks som Web of Science og Scopus, dog adskiller tjenesten sig på væsentlige punkter, idet det først og fremmest er et indeks, der anvender de sociale medier som Twitter og Facebook. Navnet Altmetrics bliver af flere tolket som "metrics of impact alternative to standard citations level". ${ }^{10}$ Under alle omstændigheder.... det er godt at være repræsenteret de steder, hvor brugerne færdes.

Statsbiblioteket og AU Library vil i løbet af efteråret rulle vores DOI-service ud til alle vores OJStidsskriftsredaktioner. Inden da vil redaktionerne modtage en mail, hvor vi specifikt angiver de krav, som de redaktioner, der måtte ønske at blive en del at DOI-systemet, skal leve op til. For ligesom man eksempelvis under anvendelsen af anerkendte citationsstandarder må overholde visse fastlagte regler, gælder dette også anvendelsen af DOI. Herom senere.

\section{Eksterne links:}

http://www.doi.org/ http://www.doi.org/hb.html https://en.wikipedia.org/wiki/Digital object identifier http://www.crossref.org/

\footnotetext{
${ }^{6}$ http://www.apastyle.org/learn/faqs/what-is-doi.aspx og http://www.lib.unimelb.edu.au/recite/citations/chicago/ref344elecSourceArticleWithDOI.html?style=3\&type $=2 \&$ detail $=6$

${ }^{7}$ http://search.crossref.org/

8 "CrossRef gives your DOIs added exposure. CrossRef is the only DOI registration agency with a cross-publisher linking network. With your publications registered in the CrossRef database, over 4500 participating organizations - other publishers, A\&I databases, aggregators, and libraries - will be able to link automatically to your content. "- See more at: http://www.crossref.org/02publishers/index.html\#sthash.wJDGGWHS.3sUQOKNZ.dpuf

${ }^{9}$ http://altmetrics.org/manifesto/. Du kan selv tilmelde dig Altmetrics via http://www.altmetric.com/bookmarklet.php

${ }^{10} \mathrm{http}$ ://openscience.com/altmetrics-fancy-feature-or-peer-reviews-successor/
} 